\title{
Struktur Cerpen "Yuki no Hi” Karya Higuchi Ichiyō
}

\author{
Zaki Ainul Fadli*, Dewi Kusmiati \\ Fakultas Ilmu Budaya, Universitas Diponegoro \\ *Email: zakiaf@live.undip.ac.id
}

\begin{abstract}
Short stories are one type of modern literary work that has the privilege of forming a whole short story but still interesting for readers. The whole story in the short story cannot be separated from the elements that make it up. Th is study aimed to determine the intrinsic elements of the short story Yuki no Hi by Higuchi Ichiyo. The elements analyzed were themes and messages, characters and characterizations, plot, setting, and point of view. The theory used is the theory of structuralism with literature review techniques and qualitative analysis techniques. This research shows that the structure of this short story forms a unity of an exciting story from beginning to the end because of the integration of intrinsic elements in supporting the story presented. In addition, the use of deautomation techniques that delay the reader's understanding until the end of the story has succeeded in making the suspense of the story more interesting.
\end{abstract}

Keywords: Higuchi Ichiyō; intrinsic element; Yuki no Hi

\section{Pendahuluan}

Prosa sebagai salah satu genre sastra terus berkembang seiring zaman hingga menghasilkan jenis karya sastra yang beragam, salah satunya adalah cerpen yang termasuk ke dalam jenis sastra modern. Cerpen secara sederhana dapat diartikan sebagai karya sastra yang lebih singkat daripada genre lain, umumnya novel (Friedman, 2014, p. 15; Pasco, 1993, p. 443). Cerpen juga mengandung masalah atau konflik yang lebih padu dan plot tunggal yang terfokus ke akhir cerita (Rokhmansyah, 2014, p. 32).

Era Meiji menjadi titik awal lahirnya kesusastraan Jepang modern yang dipengaruhi oleh proses westernisasi dan modernisasi di berbagai aspek kehidupan masyarakat Jepang (Aminah, 2015, p. 12). Hal tersebut diawali dengan banyaknya karya-karya Barat yang diterjemahkan oleh penulis-penulis Jepang, salah satunya adalah Higuchi Ichiyō (1872-1896). Higuchi Ichiyō adalah nama pena dari penulis wanita Jepang profesional yang diakui di era Meiji, Higuchi Natsuko. Karya-karyanya berupa puisi klasik dan cerpen. Higuchi juga meninggalkan sebuah catatan harian yang ia tulis semasa hidupnya. Karya-karya terkenal Higuchi antara lain Nigorie, Juusan'ya, Yuki no Hi, Hanagomori, dan Takekurabe (Growing Up). Takekurabe terbit pada April 1896 dalam majalah Bungei Kurabu (The Literature Club) menjadi karya Higuchi yang paling terkenal hingga saat ini. Higuchi menjadi perempuan ketiga yang potretnya diabadikan dalam uang kertas Jepang. Higuchi Ichiyō merupakan salah satu dari penulis brilian dan dianggap sebagai "canonical Meiji woman" karena caranya menggambarkan kehidupan masyarakat kelas bawah di Tokyo dengan cara yang elegan di dalam karya-karyanya (Sires, 2018, p. 12).

Penelitian terhadap Higuchi Ichiyo dan karyanya antara lain mengenai sentimentalisme tokoh utama wanita dalam cerpen Juusan'ya dalam The Journal of Japanese Studies. Kebanyakan karya Ichiyo menceritakan para wanita yang 
terperangkap dalam matriks gender dan dominasi kelas yang mengarah pada kehidupan subordinasi, kesengsaraan, dan bahkan akhir yang tragis (Compernolle, 2004). Penelitian lainnya adalah mengenai ketidakadilan gender dalam cerpen Nigorie (Nabila, 2018). Sedangkan objek dalam penelitian ini adalah cerpen berjudul Yuki no $\mathrm{Hi}$, karya Higuchi yang terbit di majalah Bungakkai pada tahun 1893 dan dianalisis dengan menggunakan pendekatan struktural.

Struktur pada dasarnya dapat diartikan bahwa sebuah karya menjadi suatu keseluruhan karena ada hubungan timbal balik antara unsur atau bagianbagiannya (Manshur, 2019, p. 83). Karya sastra dipandang sebagai sesuatu yang otonom, berdiri sendiri, bebas dari pengarang, realitas, maupun pembaca (Saleh, 2014, p. 148; Yulianti, 2013). Analisis struktural karya sastra dapat dilakukan dengan mengkaji dan mendeskripsikan fungsi dan hubungan antar unsur yang berhubungan. Dalam bukunya, Noor menjelaskan bahwa strukturalisme adalah aliran ilmu dan kritik yang memusatkan perhatian pada relasirelasi antar unsur (2015). Strukturalisme hanya menilai karya sastra dari segi intrinsiknya, bukan dari segi ekstrinsiknya (Saleh, 2014, p. 149). Oleh karena itu, dalam tulisan ini struktur cepen yang dimaksud adalah inner strukturnya, yaitu unsur intrinsik.

Tujuan dari penelitian ini adalah untuk mengungkap struktur (unsur intrinsik) cerpen Yuki no Hi karya Higuchi Ichiyō sehingga dapat memperluas wawasan mengenai karya sastra Jepang modern.

\section{Metode}

Metode yang digunakan dalam penelitian ini adalah metode strukturalisme dengan menggunakan teknik telaah pustaka dan teknik analisis. Teknik telaah pustaka dilakukan dengan mengumpulkan datadata dari berbagai sumber bacaan seperti buku, artikel, esai, dan lain sebagainya yang berkaitan dengan objek penelitian.Teknik analisis data yang digunakan penulis dalam penelitian ini adalah secara kualitatif yang hasilnya berupa uraian atau penafsiran. Data mengenai objek penelitian cerpen Yuki no $\mathrm{Hi}$ diperoleh dari situs Aozora Bunko dan terjemahan bahasa Inggris berupa e-book yang diperoleh dari situs Internet Archive, selanjutnya penulis analisis dengan menggunakan teori struktural karya sastra.

\section{Hasil Dan Pembahasan}

Prosa terdiri dari dua unsur, yaitu unsur intrinsik dan unsur ekstrinsik (Rokhmansyah, 2014, p. 32). Menurut Nurgiyantoro, unsur intrinsik adalah unsurunsur pembangun karya sastra itu sendiri. Unsur-unsur intrinsik tersebut jalinmenjalin secara struktural hingga membentuk suatu karya sastra (2000, p. 23). Unsur intrinsik yang dianalisis adalah tema dan amanat, tokoh dan penokohan, alur, latar, dan sudut pandang.

\subsection{Struktur (Unsur Instrinsik) Cerpen}

\subsubsection{Tema dan Amanat}

Dalam Kamus Besar Bahasa Indonesia, tema diartikan sebagai pokok pikiran atau dasar cerita (yang dipercakapkan, dipakai sebagai dasar mengarang, menggubah sajak, dan sebagainya). Tema dalam karya sastra adalah ide pokok yang mendasari keseluruhan cerita. Tema tidak dikatakan secara eksplisit oleh pengarang sehingga tema cenderung bisa diketahui atau ditemukan ketika pembaca telah memahami keseluruhan cerita. Amanat adalah pesan moral yang ingin 
disampaikan oleh pengarang kepada pembaca dan biasanya bermanfaat bagi pembaca.

Tema dari cerpen $Y u k i$ no $\mathrm{Hi}$ adalah penyesalan yang dalam akibat kenaifan di masa muda. Hal tersebut dapat dilihat dari paragraf awal cerpen yang menunjukkan penyesalan tokoh Tama atas apa yang telah dilakukannya di masa muda.

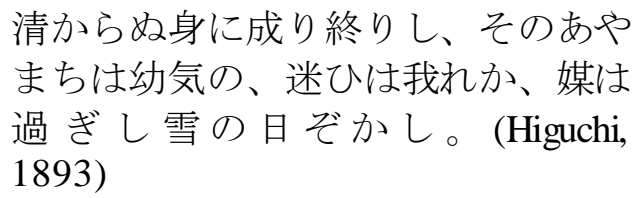

Aku terlalu muda untuk mengetahui mana yang lebih baik, cinta adalah kesalahanku, dan perantaranya adalah hari bersalju.

Tokoh Tama di masa muda merasakan jatuh cinta pertama kalinya terhadap pria sekaligus gurunya sendiri, Katsuragi Ichirō. Perasaannya tersebut ditentang oleh bibinya yang telah mengurus ia sejak kecil karena perbedaan usia dan status sosial yang dimiliki keduanya. Pada suatu hari bersalju, Tama memutuskan untuk meninggalkan semua yang ia miliki, mulai dari keluarga hingga kampung halamannya demi mewujudkan keinginannya, yaitu hidup bersama Katsuragi. Pada akhirnya mereka tidak bisa berbahagia karena perasaan bersalah dan penyesalan atas tindakan tanpa pikir panjang yang telah dilakukannya di suatu hari bersalju itu.

Berdasarkan tema yang telah dipahami tersebut, dapat disimpulkan bahwa amanat yang ingin disampaikan oleh pengarang dalam cerpen $\mathrm{Yuki}$ no $\mathrm{Hi}$ adalah agar kita senantiasa berpikir sebelum bertindak, mempertimbangkan sisi baik dan buruk yang akan terjadi jika kita melakukan suatu hal, sehingga kita tidak menyakiti hati orang-orang terdekat kita dan menghindari penyesalan di masa depan.

\subsubsection{Tokoh dan Penokohan}

Tokoh adalah pelaku dalam cerita beserta posisi-posisinya. Dalam penelitian ini dibahas mengenai tokoh berdasarkan peranannya yaitu tokoh utama dan tokoh tambahan. Penokohan adalah bagaimana suatu tokoh atau pelaku dalam cerita digambarkan oleh pengarang. Penggambaran tokoh oleh pengarang dapat dilakukan dengan teknik ekspositori (secara langsung melalui deskripsi dari pengarang) dan teknik dramatik (secara tidak langsung, misalnya dilihat dari percakapan, respons tokoh lain, atau tingkah laku tokoh tersebut).

Tokoh utama dalam cerpen Yuki no $H i$ adalah Tama. Selain karena Tama adalah narator dalam cerpen ini, Tama merupakan tokoh yang ada dari awal cerita hingga akhir sehingga frekuensi kehadirannya dalam cerita lebih banyak dibandingkan tokoh-tokoh lainnya.

我が名の珠に恥かしき今日、親は眼 なかれとこそ名づけ給ひけめ (Higuchi, 1893)

Orang tua menamaiku Tama dengan harapan aku sempurna tanpa cacat, dan hari ini aku malu menyandang nama itu.

Tokoh Tama digambarkan sebagai gadis disukai orang-orang namun seorang yang polos. Hal tersebut bisa disimpulkan dari kutipan berikut.

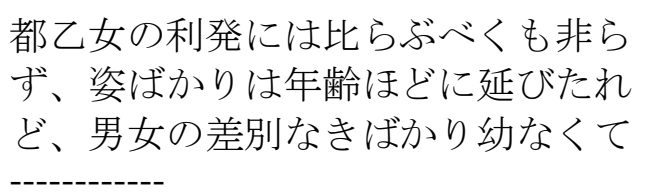

ず、姿ばかりは年齢ほどに延びたれ ど、男女の差別なきばかり幼なくて 
年来としごろ美事に育だて上げて、 人にも集められ我れも誇りし物を、 (Higuchi, 1893)

Gadis desa ini tidak setara dengan gadis kota, hanya penampilannya sesuai untuk gadis seusiaku, aku adalah anak kecil yang belum mengerti perbedaan antara pria dan wanita---------------Bertahun-tahun ini, aku telah membesarkanmu dengan sangat hatihati. Orang-orang selalu mengatakan betapa cantiknya dirimu. Aku sangat bangga padamu.

Dilihat dari penokohannya, terlihat bahwa karakter tokoh utama bersifat kompleks, tidak hanya memiliki satu tipe karakter, sehingga tokoh Tama dapat digolongkan sebagai tokoh bulat/ round character.

Tokoh selanjutnya adalah sang Bibi yang merupakan tokoh tambahan karena walaupun keberadaannya cukup berpengaruh terhadap keseluruhan cerita, tetapi hanya muncul di tengah-tengah cerita.

伯母の是れも良人を失なひたるが、 立帰りて我をば生したて給ひにき (Higuchi, 1893)

Bibiku pulang ke kampung halaman kami setelah suaminya meninggal untuk mengasuhku.

Tokoh Bibi digambarkan memiliki sifat penyayang tetapi merawat Tama dengan aturan-aturan yang sangat tegas dan konvensional. Hal ini dapat dilihat dari kutipan berikut.

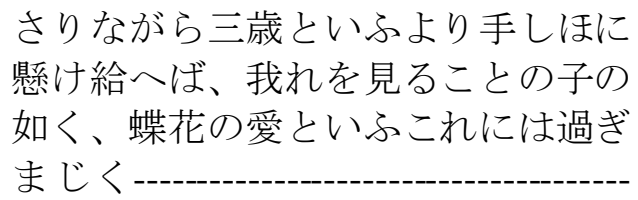

されども此処にありて、我が薄井の 家には昔しより他郷の人と縁を組ま ず

(Higuchi, 1893)

Sejak aku berusia 3 tahun, ia (bibi) mengabdikan dirinya untuk mengasuhku seperti anaknya sendiri. cinta yang ia berikan kepadaku adalah seperti cintanya kupu-kupu dengan bunga.

Tetapi kau tahu ada aturan-aturan yang harus dipatuhi, di keluarga kita tidak ada yang pernah menikah dengan seseorang dari luar desa, apalagi ia yang datang dari Tokyo.-----------------------

Tokoh tambahan yang kedua adalah Katsuragi Ichirō, seorang guru pendatang dari Tokyo yang tinggal tidak jauh dari Tama dan mengajar di sekolahnya.

ぬれにし袖の相手といふは、桂木一 郎とて我が通学せし学校の師なり (Higuchi, 1893)

Penyebab dari derasnya air mataku adalah Katsuragi Ichirō, seorang guru yang mengajar di sekolahku.

Tokoh Katsuragi yang digambarkan melalui sudut pandang Tama adalah pria berusia 30 tahunan yang tampan dan ia belajar banyak hal dari Katsuragi. Tama tidak memiliki saudara, oleh karena itu ketika ia diperlakukan seperti adik oleh Katsuragi, ia merasa sangat senang dan perlahan ia sadar bahwa perasaan senang tersebut berubah menjadi cinta. Hal tersebut dapat dilihat dari kutipan berikut.

\footnotetext{
東京の人なりとて容貌みめうるはし $<-------$

おもしろき物がたりの中に様々教へ を含くめつ、さながら妹の如くもて なし給へば、なき身の我れも嬉しく (Higuchi, 1893)
} 
Ia (Katsuragi) datang dari Tokyo-------Ia selalu mengatakan hal-hal yang menarik, dan aku belajar banyak dari pembicaraanku dengannya. Ia memperlakukanku seperti adiknya, dan aku yang tidak mempunyai saudara ini, tentu saja merasa sangat senang.

Tokoh yang terakhir adalah Heisuke, seorang pekerja tani di kediaman Tama yang muncul dan membuatnya terkejut saat berusaha melarikan diri di hari bersalju. Ia digambarkan sebagai seorang pria yang bodoh. Hal ini dapat dilihat dari kutipan berikut.

\section{お金をも持たずにかと驚ろかせし は、作男の平助とてに愚かなる男な りし (Higuchi, 1893)}

Tanpa bertanya apakah aku bawa payung atau tidak, aku dikejutkan oleh pekerja tani di rumah kami, Heisuke. Ia adalah pria yang bodoh.

\subsubsection{Alur}

Alur atau plot adalah rangkaian-rangkaian peristiwa yang disampaikan dalam cerita yang memiliki hubungan sebab akibat. Alur dibedakan menjadi 3 jenis, yaitu alur progresif (jalan cerita runtut dengan waktu atau kronologis), alur regresif (diceritakan secara tidak berurutan atau kilas balik), dan alur campuran (mengombinasikan alur progresif dan alur regresif).

Alur yang digunakan pengarang dalam cerpen $\mathrm{Yuki}$ no $\mathrm{Hi}$ adalah alur campuran karena urutan cerita dimulai dari waktu saat ini ketika tokoh utama mengalami penyesalannya. Selanjutnya, keseluruhan kisah diceritakan melalui kilas balik secara kronologis, dimulai dari pengenalan latar belakang tokoh Tama. Tama yang merupakan anak tunggal dari keluarga Usui yang merupakan keluarga terpandang di desanya, namun kedua orang tuanya meninggal sejak ia kecil sehingga ia diasuh dan dibesarkan oleh Bibinya. Tama tumbuh menjadi gad is yang ceria tetapinaif dan keras kepala. Pada saat perasaan cinta kepada gurunya, Katsuragi, ditentang oleh Bibi dan orang-orang di lingkungannya, ia membulatkan tekad untuk tetap mewujudkan keinginannya untuk hidup bersama Katsuragi dengan melarikan diri dari rumah ketika sang Bibi pergi mengunjungi kerabat. Namun, kisahnya berakhir dengan kembali ke waktu saat ini, di mana ia mengingat kembali saat ia mendapat kabar bahwa sang Bibi meninggal putus asa di tahun yang sama karena kepergiannya bersama Katsuragi, penyesalan yang Tama rasakan tidak pernah bisa ia lupakan. Hal ini dapat dilihat dari kutipan berikut.

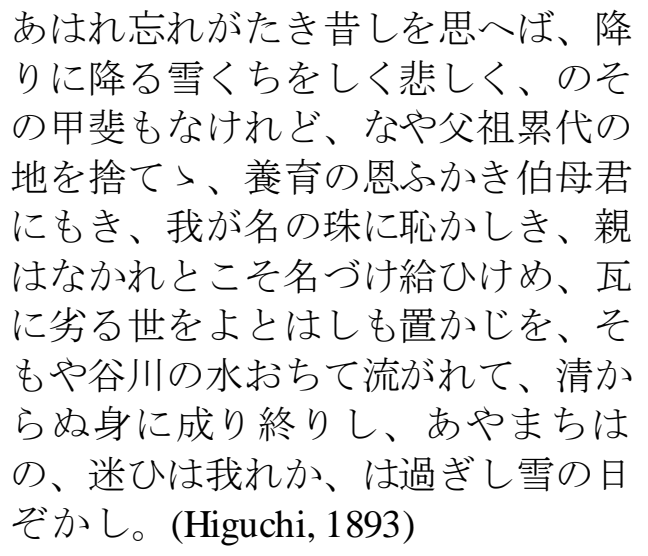

Tetapi bagiku, salju mengundang rasa sakit yang baru, mengundang dengan setiap rintikannya di masa lalu yang tak terlupakan. Delapan ribu penyesalan yang aku miliki, betapa kecilnya kebaikan yang mereka bawa kepadaku. Betapa sia-sia, aku telah membuang kehidupanku, warisan keluargaku. Aku telah memunggungi makam leluhurku dan melarikan diri dari seorang bibi yang memberiku segalanya. Orang tua menamaiku Tama -permata- seolah-olah aku akan menjadi orang yang tetap berharga dan sempuma. Betapa aib yang telah aku bawa pada namaku! 
Bagaimana mereka bisa mengira bahwa aku akan berakhir sama tidak berharganya dengan pecahan ubin? Aku telah jatuh seperti sampah ke sungai dan hanyut ke air yang tercemar. Aku terlalu muda untuk mengetahui mana yang benar, cinta adalah kesalahanku, dan perantaranya adalah hari bersalju.

Di akhir cerita, pembaca baru mengetahui bahwa Tama meninggalkan rumahnya karena diajak untuk kawin lari oleh Katsuragi. Akhirnya Tama menikah dengan Katsuragi dan tinggal di Tokyo seperti yang tergambar pada kutipan berikut.

\section{今さらに我が夫を恨らみんも果敢な し、都は花の見る目うるはしきに、 深山木の我れ立ち並らぶ方なく、草 木の冬と一人しりて、袖の涙に昔し を問へば、何ごとも総すべて誤なり き、故郷の風の便りを聞けば、伯母 君は我が上を歎げき歎げきて、其歳 の秋かなしき数に入り給ひしとか、 悔こそ物の終りなれ、今は浮世に何 事も絶えぬ、つれなき人に操を守り て知られぬ節ふしを保たもたんの み、思へば誠と式部が歌の、ふれば 憂さのみ増さる世を、知らじな雪の 今歳も又、我が破れ垣をつくろひ て、見よとや誇る我れは昔しの恋し き物を。(Higuchi, 1893)}

Terlepas dari cintaku pada Katsuragi, bahkan dalam mimpiku aku tidak pemah membayangkan bahwa dia akan menjadi suamiku, atau kami berdua akan melarikan diri. Tapi bersama-sama kami mengembara tanpa tujuan. Seperti bambu hitam di bawah jendela, dibengkokkan oleh salju tebal, dia dan saya dihancurkan oleh hebatnya pelanggaran kami. Meninggalkan tempat kelahiranku, membuang bibi tercinta - itu semua adalah kegilaan hari bersalju itu. Di sini, di kemegahan ibu kota aku merindukan teman-teman negaraku, tetapi pada kencan yang terlambat ini adalah sia-sia untuk menyalahkan suamiku karena telah membawaku pergi, "

\subsubsection{Latar}

Latar merupakan suatu keadaan yang bisa berupa tempat, waktu, suasana, dan sosial budaya. Latar yang bisa ditemukan dalam cerpen ini adalah latar tempat, latar waktu, latar suasana, dan latar sosial budaya.

Latar tempat pada cerpen ini adalah sebuah desa di pegunungan, tempat keluarga Usui, rumah Tama di masa muda. Latar tempat berikutnya adalah ibu kota tempat Tama tinggal saat ini bersama dengan suaminya, Katsuragi. Hal tersebut dapat dilihat dari kutipan berikut.

我が故郷は某の山里、草ぶかき小村 なり

今さらに我が夫を恨らみんも果敢な し、都は花の見る目うるはしきに。. (Higuchi, 1893)

Rumahku berada di desa pegunungan, di mana rumput tumbuh dengan lebat.----Bahkan sekarang, saya tidak berani mendendam suami saya, dan kota ini penuh dengan bunga

Latar waktu yang bisa ditemukan dalam cerpen ini sebagian besar adalah pada saat musim dingin. Hal tersebut berkaitan dengan judul $Y u k i$ no $H i$ yang berarti hari bersalju. Selanjutnya, dapat ditemukan latar waktu lain, yaitu hari ketujuh setelah tahun baru. Berikut kutipan-kutipan yang menunjukkan latar waktu pada cerpen Yuki no Hi.

$$
\begin{aligned}
& \text { 何ごとの憂きもなく思慮もなく明し } \\
& \text { 暮らす十五の冬....---- } \\
& \text { いわふの、歳たちかへつて七日の日 } \\
& \text { りき、伯母君は隣村の親族がり年始 }
\end{aligned}
$$


の礼にと趣き給ひしが (Higuchi, 1893)

Pada musim dingin kelima belas aku hidup tanpa kekhawatiran..

Tahun baru telah tiba, waktu untuk perayaan dan kegembiraan. Pada hari ketujuh, Bibi mengunjungi kerabat yang berada di desa tetangga.

Latar suasana yang dapat ditemukan dalam cerpen ini adalah suasana hari bersalju di hari Tama meninggalkan rumahnya. Suasana hari bersalju tersebut menyiratkan kesedihan dan kehampaan yang Tama rasakan saat ia sangat merindukan Katsuragi lalu memutuskan untuk melarikan diri bersamanya dan saat ia mengingat bahwa justru tindakannya saat itulah yang menyebabkan penyesalan dalam di kemudian hari.

\section{朝より曇り勝の空いや暗らく成る ま〉に、吹く風絶へたれど寒さ骨に しみて、引入るばかり物心ぼそくな がむる空に白き物ちら、こそ雪に成 りぬるなれ....とど降る雪なく綿を なげて、時の間に隠くれけり庭もも} (Higuchi, 1893)

Sejak pagi cuaca mendung dan langit semakin gelap. Tiupan angin perlahan mereda, tetapi hawa dinginnya cukup menusuk tulang... sekarang salju turun dengan lebat, terlihat seperti kumpulan kapas. Sebentar lagi semua akan tersembunyikan olehnya, taman, dan juga gerbang.

Cerpen ini dilatarbelakangi oleh kondisi masyarakat yang masih menjunjung tinggi martabat keluarga. Kehormatan keluarga adalah hal yang paling penting daripada cinta. Hal tersebut dapat dilihat dari kutipan berikut.

よく聞けよお珠、桂木様は其方を愛 で給ふならん、其方も又慕はしかる
ベし、されども此処にありて、我が 薄井の家には昔しより他郷の人と縁 を組まず、てや如何に学問は長じ給 ふとも、桂木様は何者の子何者の種 とも知らぬを、なる我が薄井の聟と も言ひがたく嫁にもりがたし (Higuchi, 1893)

Dengarkan aku, Tama. Tuan Katsuragi mungkin sangat mencintaimu, dan kau juga mencintainya. Tetapi kau tahu ada aturan-aturan yang harus dipatuhi, di keluarga kita tidak ada yang pernah menikah dengan seseorang dari luar desa, apalagi ia yang datang dari Tokyo. Tidak peduli seberapa baik dan terpelajarnya Tuan Katsuragi, kita tidak tahu apapun mengenai latar belakang dirinya. Tidak mungkin bagiku untuk mempertimbangkan ia sebagai menantu.

\subsubsection{Sudut Pandang}

Sudut pand ang merupakan dari posisi mana (siapa) peristiwa dan tindakan dalam cerita dilihat. Sudut pandang dibagi menjadi 3 jenis, yaitu sudut pandang persona ketiga (pengarang membatasi dirinya dengan tokoh-tokoh yang ada dalam cerita, sehingga tokoh-tokoh tersebut akan disebut dengan "dia" oleh narator yang bersifat maha tahu), sudut pandang persona pertama (melibatkan tokoh tertentu sehingga menggunakan kata "aku" sebagai narator dalam cerita), dan sudut pandang campuran.

Dalam cerpen Yuki no $\mathrm{Hi}$, pengarang menggunakan sudut pandang persona pertama. Hal tersebut ditandai dengan penggunaan kata ganti orang pertama “我” yang berarti “aku” sebagai narator dalam keseluruhan cerita.

\subsection{Diskusi}

Seorang penulis atau pengarang bisa jadi mendapatkan inspirasi untuk menuliskan kejadian yang dialaminya 
sendiri dalam karya sastranya (Fadli \& Hastuti, 2017). Sebuah karya sastra menyajikan gambaran kehidupan, dan kehidupan itu sendiri adalah realitas sosial (Fadli, 2020). Di dalam tulisan Tanaka (1956) menyatakan Higuchi yang jatuh cinta kepada Tōsui Narakai (mentornya) dan berujung pada kekecewaan dan membawa penyesalan baginya. Lebih jauh, Tanaka menuliskan bahwa peristiwa itu menjadi sumber inspirasi bagi dirinya dalam menulis cerpen Yuki no $\mathrm{Hi}$ (1956, p. 182). Menarik untuk diteliti lebih lanjut mengenai kaitan cerpen ini dengan pengalaman hidup penulisnya.

\section{Simpulan}

Berdasarkan hasil dan pembahasan analisis unsur intrinsik cerpen Yuki no Hi karya Higuchi Ichiyō, dapat diperoleh simpulan bahwa hal yang menjadi gagasan pokok cerpen $Y u k i$ no $H i$ adalah penyesalan akibat tindakan naif di masa lalu. Latar-latar yang digunakan dalam cerpen ini bisa dengan mudah dibayangkan oleh pembaca walaupun dengan penjelasan yang terbatas. Latar tempat, desa pegunungan dan ibu kota; latar waktu dan suasana yang berkaitan dengan judul, yaitu musim dingin; dan latar sosial budaya yang berkaitan dengan era saat pengarang menulis karyakaryanya, yaitu masyarakat masih sangat menjunjung tinggi kehormatan keluarga (status sosial) di atas hal apa pun.

Judul cerpen yaitu Yuki no $\mathrm{Hi}$ menyiratkan waktu terjadinya konflik di dalam cerita. Konflik antara Tama dan bibinya terjadi pada saat musim salju turun. Konflik tersebut terjadi karena disebabkan rumor hubungan percintaan antara Tama dengan Katsuragi yang mendorong bibinya berusaha mencegah berlanjutnya hubungan Tama dengan gurunya tersebut. Tama mengalami konflik batin, di satu sisi dia memahami perasaan bibinya yang melakukan itu demi kebaikannya, dan di sisi yang lain Tama ingin terus melanjutkan hubungan percintaannya dengan gurunya. Meskipun Tama akhirnya memilih untuk melarikan diri bersama Katsuragi dan kemudian menikah dan tinggal di Tokyo, tetapi tidak kurang pula penyesalannya meninggalkan kampung halaman dan bibinya yang sangat disayanginya.

Meskipun termasuk ke dalam cerita pendek, tetapi cerita dalam Yuki no $\mathrm{Hi}$ mampu diceritakan dengan alur cerita yang membuat pembaca tertarik membacanya sampai akhir. Suspense cerita mencapai klimaksnya di akhir cerita ketika Tama sebagai narator baru menceritakan bahwa Katsuragi adalah suaminya dan sekarang tinggal bersamanya di Tokyo. Di bagian ini dapat dirasakan teknik deotomatisasi dipakai oleh pengarang untuk menunda pemahaman pembaca sampai di akhir cerita.

Sudut pandang persona pertama yang digunakan pengarang dalam cerita ini mampu menjadikan cerita ini menarik karena tokoh utama menceritakan kejadiankejadian yang dialaminya dari sudut pandangnya. Pembaca menjadi mengetahui konflik batin yang dialami tokoh utama karena yang menjadi narator cerita adalah tokoh utama sendiri.

Struktur cerpen di atas saling berkolerasi dan membentuk satu kesatuan cerita yang utuh dan menarik untuk dibaca.

\section{Referensi}

Aminah, S. (2015). Dinamika Kesusastraan Jepang Modern Ambiguitas antara Tradisi dan Modernitas. Retrieved April 14, 2021, from https://www.researchgate.net/publica tion/313339909_DINAMIKA_KESU SASTRAAN_JEPANG_MODERN_ Ambiguitas_antara_Tradisi_dan_Mo dernitas 
Burhan, N. (2000). Teori Pengkajian Fiksi. Gadjah Mada University Press.

Compernolle, T. J. van. (2004). Happiness Foreclosed: Sentimentalism, the Suffering Heroine, and Social Critique in Higuchi Ichiyō's "Jūsan'ya." The Journal of Japanese Studies, 30(2), 353-381. https://doi.org/10.1353/jjs.2004.0078

Fadli, Z. A. (2020). Story Meaning in Warera no Jidai no Fuukoroa -Koodo Shihon Shugi Zenshi by Murakami Haruki. E3S Web Conf., 202. Retrieved from https://doi.org/10.1051/e3sconf/2020 20207030

Fadli, Z. A., \& Hastuti, N. (2017). TEMA CINTA DALAM NOVEL SHIOSAI KARYA MISHIMA YUKIO. IZUMI. https://doi.org/10.14710/izumi.6.1.45 $-52$

Friedman, N. (2014). Recent Short. Story Theories: Problems in Definition. Retrieved April 29, 2021, from https://vd ocuments.site/normanfried man-recent-short-storytheories.html

Manshur, F. M. (2019). KAJIAN TEORI FORMALISME DAN STRUKTURALISME. Gadjah Mada Journal of Humanities, 3(1), 79-93. Retrieved from https://jurnal.ugm.ac.id/sasdayajourn al/article/download/43888/23942

Nabila, S. (2018). Ketidakadilan Gender dalam Cerpen Nigorie Karya Higuchi Ichiyō, Kajian Feminisme. Universitas Diponegoro. Retrieved from http://eprints.undip.ac.id/68274/1/SK RIPSI_FULL.pdf

Noor, R. (2015). Pengantar Pengkajian Sastra. Semarang: Fasindo.

Pasco, A. H. (1993). The Short Story: The Short of It. Style, 27(3), 442-451. Retrieved http://jstor.proxy.undip.ac.id:2048/sta ble/42946063

Rokhmansyah, A. (2014). Studi dan Pengkajian Sastra; Perkenalan Awal terhadap Ilmu Sastra. Yogyakarta: Graha Ilmu.

Saleh, F. (2014). Teori Formalisme Balaghah. Al-Turas, 20(1), 147-157.

Sires, P. M. (2018). Higuchi Ichiyō In Modern Japanese And European Dress: Modern Japanese versions (gendaigoyaku) of Higuchi Ichiyō's Takekurabe and their Relationship with English, Castilian Spanish and Catalan Translations. Waseda University. Retrieved from https://core.ac.uk/download/pdf/1595 04337.pdf

Tanaka, H. (1956). Higuchi Ichiyō. Monumenta Nipponica, 12(3/4), 171194. https://doi.org/10.2307/2382751

Yulianti, A. M. (2013). Analisis Struktural dan Nilai Moral Cerpen Tebukuro wo Kai ni 「手袋を買いに」Karya Niimi Nankichi. Universitas Diponegoro. Retrieved from https://fib.undip.ac.id/digilib/home/fi b.undip.ac.id/files/e_book/skripsi ayu mustika.pdf 